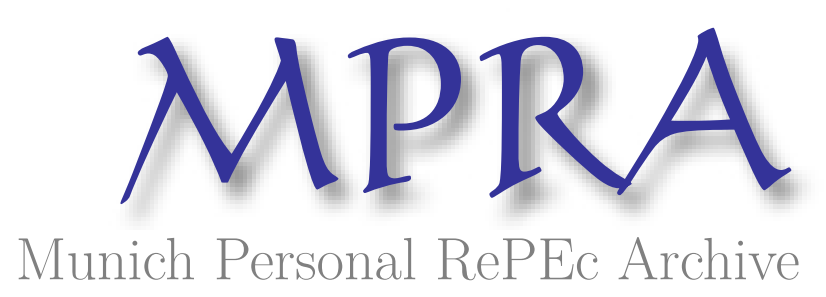

\title{
From Fixed to Float: A Competing Risks Analysis
}

Chong, Terence Tai Leung and He, Qing and Chan, Wing Hong

The Chinese University of Hong Kong and Nanjing University, Renmin University of China, Wilfrid Laurier University

22 December 2014

Online at https://mpra.ub.uni-muenchen.de/60824/

MPRA Paper No. 60824, posted 22 Dec 2014 13:17 UTC 


\title{
From Fixed to Float: A Competing Risks Analysis
}

\author{
Terence Tai-Leung Chong ${ }^{1}$ \\ Department of Economics, The Chinese University of Hong Kong \\ and Department of International Economics and Trade, Nanjing University. \\ Qing He \\ School of Finance and China Financial Policy Research Center \\ Renmin University of China, China \\ and \\ Wing Hong Chan \\ School of Business and Economics, Wilfrid Laurier University, Canada
}

$22 / 12 / 14$

\begin{abstract}
This paper examines the determinants of exchange rate regime of a country. A competing risks model (CRM) is estimated. It is found that the way a country exits a fixed exchange rate regime is affected nonlinearly by the duration of the peg. In addition, countries with a lower growth rate of reserves, more incidences of banking crises, higher trade concentration and lower degree of capital-account liberalisation are more likely to have a crisis-driven exit.
\end{abstract}

Keywords: Competing risks model; Duration dependence; Orderly exits; Crisisdriven exits; Kaplan-Meier estimators.

JEL classification: F3, C41, C54

\footnotetext{
${ }^{1}$ We would like to thank Yin Wong Cheung, Kang Shi and Julan Du for helpful comments. We are also grateful to Min Chen, Margaret Loo, Jonathan Siu, Kun Ma and Mansfield Wong for their research assistance. Any errors are ours alone. This research is supported by the Programme for New Century Excellent Talents in University of the Ministry of Education of China (NCET-11-0495). Corresponding Author: Terence Tai-Leung Chong, Department of Economics, The Chinese University of Hong Kong, Shatin, N.T., Hong Kong. E-mail: chong2064@cuhk.edu.hk. Homepage: http://www.cuhk.edu.hk/eco/staff/tlchong/tlchong3.htm.
} 


\section{Introduction}

A number of countries have abandoned the fixed exchange rate regime and adopted a relatively floating exchange rate arrangement following the collapse of the Bretton Woods system. Some of these countries (for example, Japan and Israel) managed to switch to a floating regime without triggering a currency crisis. However, for most countries, the transitions have seldom been smooth. Eichengreen (1999) argues that exits from a pegged exchange rate system have rarely occurred under favourable circumstances. For example, in the cases of Mexico, Thailand and Argentina, the exits were triggered by speculative attacks. A number of studies have developed models on the optimal timing of switching the exchange rate regime (Krugman, 1979; Flood and Garber, 1984; Rebelo and Vegh, 2008). It has been well documented that the duration of the peg plays an important role in the decision to exit the fixed exchange rate regime. For example, Klein and Marion (1997) show that the longer a peg lasts, the more likely it is to collapse. Walti (2005) finds a non-monotonic relationship between the peg duration and the probability of its collapse. Masson and Ruge-Murcia (2005) study the transition between exchange rate regimes using a Markov chain model with time-varying transition probabilities. Klein and Shambaugh (2006) also show that peg duration affects the collapse of an exchange rate regime. Tamgac (2013) finds nonmonotonic duration dependence of fixed exchange rate regimes in emerging economies.

The aforementioned studies, however, rarely distinguish different modes of exits. This paper examines the relationship between the duration and the modes of leaving a fixed exchange rate system. Pertinent research in this area is rather limited. A related study conducted by Duttagupta and Otker-Robe (2003) concludes that peg duration significantly affects the modes of exits. However, their models suffer from the problem of survivorship bias. In this paper, we apply the competing risks model to assess the impact of a peg duration and different time dependent variables on the odds of different exits. The competing risks model (CRM) has wide economic applications. For example, He et al. (2010) apply the model to study the delisting behaviour of public firms, and D'Addio and Rosholm (2005) estimate a CRM for exits from temporary jobs in Europe. We will use the CRM model to distinguish the characteristics of successful transitions (orderly exits) from the failures (crisis-driven 
exits). It is found that crisis-driven exits exhibit positive duration dependence, while orderly exits exhibit negative duration dependence. Moreover, an increase in trade concentration lowers the chance of an orderly exit. Countries with a lower growth rate of foreign currency reserves and more incidences of banking crises are more likely to have crisis-driven exits. Finally, our findings show that degrees of capital-account liberalisation are positively related to the chance of an orderly exit.

The remainder of this paper is organised as follows. Section 2 describes the data and variables used. Section 3 briefly reviews the methodology of the competing risks model. The estimation results are presented in Section 4. Section 5 concludes the paper.

\section{Data}

Our sample consists of monthly data for the peg duration and country-specific variables from 77 countries for the period from January 1972 to December 2001. As the actual exchange rate arrangements of countries might differ from the official announcements, we use the de facto classification method of Reinhart and Rogoff (2004), hereafter "RR", to construct the sample of peg durations. ${ }^{2}$ In accordance with Reinhart and Rogoff (2004), we define an exit from a fixed exchange rate regime to a flexible one as a shift from any fixed categories to managed floating, freely floating or freely falling. Following Duttagupta and Otker-Robe (2003), a crisis-driven exit is identified if the end-of-month exchange rate movement is larger than two times the standard deviation of the monthly depreciation rate, i.e.,

$\varepsilon_{t} \geq \bar{\varepsilon}+2 \sigma$

where ${ }^{\varepsilon_{t}}$ is the average monthly depreciation rate of nominal exchange rate at the time of regime shift (units of the national currency per U.S. dollar), $\bar{\varepsilon}$ is the average of monthly depreciation rate during a given peg, $\sigma$ is the standard deviation of

\footnotetext{
${ }^{2}$ Other de facto classifications include Shambaugh (2004).
} 
monthly depreciation rate during the same period. The remaining exits are treated as orderly exits. The results of our crisis-driven classification are similar to those of Glick, Guo and Hutchison (2006). To provide a robustness check, we also follow the method of Detregiache et al. (2005) and Lin and Ye (2011) to define crisis-driven exits, and find that our results remain unchanged.

The duration of an exchange rate peg is defined as the time spent on a peg. One hundred and thirty three duration observations are obtained from the sample; 82 pegged durations end in or before December, 2001; and the remaining 51 observations are right-censored. The definitions of variables and data descriptions are given in Tables 1 and 2 respectively.

Table 1: Definition of Variables and Data Sources

\begin{tabular}{|c|c|c|}
\hline Variables & Descriptions & Data Sources \\
\hline OPENNESS & $\begin{array}{l}\text { Total gross exports and } \\
\text { imports, percent of GDP }\end{array}$ & $\begin{array}{l}\text { IMF, International } \\
\text { Financial Statistics }\end{array}$ \\
\hline CONCENTRATION & $\begin{array}{l}\text { Share of total exports to } 3 \\
\text { largest trading partners }\end{array}$ & $\begin{array}{l}\text { Ghosh, Gulde, and } \\
\text { Wolf (2003) }\end{array}$ \\
\hline INFLATION & $\begin{array}{l}\text { Change in consumer prices, } \\
\text { percent of per annum }\end{array}$ & $\begin{array}{l}\text { IMF, International } \\
\text { Financial Statistics }\end{array}$ \\
\hline GDP_GROWTH & $\begin{array}{l}\text { Real GDP growth rate, } \\
\text { percent of per annum }\end{array}$ & $\begin{array}{l}\text { World } \quad \text { Economic } \\
\text { Outlook }\end{array}$ \\
\hline GDP_VOLATILITY & $\begin{array}{l}\text { Deviation of real GDP } \\
\text { from HP-filtered trend, 3- } \\
\text { year standard deviation }\end{array}$ & $\begin{array}{l}\text { Ghosh, Gulde, and } \\
\text { Wolf (2003) }\end{array}$ \\
\hline BASEINTEREST & $\begin{array}{l}\text { Nominal interest rate in the } \\
\text { base country }\end{array}$ & $\begin{array}{l}\text { IMF, International } \\
\text { Financial Statistics }\end{array}$ \\
\hline CAL & $\begin{array}{l}\text { Capital-account } \\
\text { Liberalization, Total gross } \\
\text { actual foreign direct and } \\
\text { portfolio investment, }\end{array}$ & $\begin{array}{l}\text { Lane and Milesi- } \\
\text { Ferretti (2007) }\end{array}$ \\
\hline
\end{tabular}


CBI

DEMOCRACY

DEBTPOSITION

RESERVEGROWTH

HYPERINFLATION

BANKCRISIS

COUNTRYTYPE percent of GDP

Turnover rate of central Ghosh, Gulde, and bank governors Wolf (2003)

Index of democracy

Freedom House

Net debt liability, percent Lane and Milesi-

of GDP

Ferretti (2007)

Change in foreign

exchange reserves, percent

IMF, International per annum

1 if inflation above $50 \%, 0$ IMF, International otherwise

Financial Statistics

1 if there is banking crisis, Ghosh, Gulde, and 0 otherwise Wolf (2003)

1 if Developed countries, 0 otherwise

\section{Table 2 about here}

Table 3: Summary Statistics on Pegged Duration

\begin{tabular}{llll}
\hline & Full Sample & Crisis-driven Exit & Orderly Exit \\
\hline Failed & 82 & 30 & 52 \\
Censored & 51 & & \\
Mean & 131 & 128 & 71 \\
Median & 105 & 110 & 56 \\
Stdev & 111 & 93 & 65 \\
Min & 3 & 11 & 3 \\
Max & 360 & 311 & 323 \\
\hline
\end{tabular}


Table 3 summarises the statistics of durations for the two types of exits. The average duration of a peg is 131 months, the median duration is 105 months and the range of a peg duration is from 3 months to 360 months. A total of 82 failed pegs are identified, of which 30 are crisis-driven exits and 52 are orderly exits. Furthermore, a pegged exchange rate regime lasts significantly longer in crisis-driven exits than in orderly exits. We apply an array of country-specific variables in our analysis. The data for these covariates are taken from the International Financial Statistics (IFS) and other sources, covering most determinants suggested by the literature on currency crises and optimal currency areas. The macroeconomic variables included are openness, trade concentration, domestic inflation rate, economic growth and output volatility. Financial variables include base-country interest rate, ${ }^{3}$ foreign debt, capital-account liberalisation, banking crises and central bank independence. Political and institutional variables include democratisation, country type and hyperinflation. Note that the traditional measures of capital-account liberalisation are based on the IMF's Annual Report on Exchange Arrangements and Exchange Restrictions. These measures might not adequately reflect the actual or de facto exposure of countries to international capital markets. In this paper, we use the measure of capital-account liberalisation that focuses exclusively on portfolio equity and FDI holdings (Lane and Milesi-Ferretti, 2007).

\section{Methodology}

We let the peg duration be a realisation of a random variable $T$, and the indicator of the type of exits a realisation of a random variable $R$. The hazard function for an exit of type $r$ (the cause-specific hazard) is defined as

$$
h^{r}=\lim _{d t \rightarrow 0} \frac{\operatorname{Pr}(t \leq T<t+d t, R=r \mid T \geq t)}{d t} .
$$

\footnotetext{
${ }^{3}$ The base country is the one to which a country pegs its own currency (Di Giovanni and Shambaugh, 2007).
} 
Equation (2) captures the conditional probability that a peg will terminate at time $T=t$ and type $R=r$, given that it has survived till time $t$. The probability that an exit of type $r$ occurs in the interval $(t, t+d t)$ is the event-specific density function:

$f^{r}(t)=\lim _{d t \rightarrow 0} \frac{\operatorname{Pr}(t \leq T<t+d t, R=r)}{d t}=h^{r}(t) S(t)$,

where $S(t)=\operatorname{Pr}(T \geq t)$.

For country ${ }^{i}$, let $t_{i}^{1}$ be the duration of a peg before an orderly exit and $t_{i}^{2}$ be the duration of a peg before a crisis-driven exit. The two types of exits are mutually exclusive. We define

$t_{i}=\operatorname{Min}\left(t_{i}^{1}, t_{i}^{2}\right)$

Let $r_{i}$ be an indicator variable, which equals to 0 under a pegged exchange rate system, equals to 1 if there is an orderly exit from a peg to a floating and equals to 2 if there is a crisis-driven exit. We observe an event or censoring time $t_{i}$ and a categorical variable ${ }^{r_{i}}$ indicating whether they are censored. The data are censored if $r_{i}=0$ and are uncensored if $r_{i}=1$ or 2 . Considering Cox PH models of the form:

$h^{r}(t ; x)=h_{0}^{r}(t) \exp \left[x(t)^{\prime} \beta^{r}\right], \quad r=1,2$

where both the baseline hazard ratios $h_{0}^{r}(t)$ and $\beta^{r}$ are specific to type $r$ hazard, $x(t)$ is observed characteristics denoted by potential explanatory variables at time $t$ and $t_{1}^{r}<\cdots<t_{k_{r}}^{r}$ denotes the $k_{r}$ ordered failures of type $r$. The likelihood function for the Cox competing risks model is 
$L\left(\beta^{1}, \beta^{2}\right)=\prod_{r=1}^{2} \prod_{j=1}^{k_{r}} \frac{\exp \left[x_{j}\left(t_{j}^{r}\right)^{\prime} \beta^{r}\right]}{\sum_{l \in R\left(r_{j}^{r}\right)} \exp \left[x_{l}\left(t_{j}^{r}\right)^{\prime} \beta^{r}\right]}$,

where the risk set $R\left(t_{j}^{r}\right)$ is the set of fixed exchange rate spells that are at risk of collapsing before the $\mathrm{j}^{\text {th }}$ failure of type $r$. State dependence might arise due to unobserved heterogeneity. To incorporate unobserved heterogeneity into our model, ${ }^{4}$ the Cox CRM can be extended to include a multiplicative term $v$, i.e.,

$h^{r}(t ; x)=h_{0}^{r}(t) \exp \left[x(t)^{\prime} \beta^{r}\right] v^{r}, \quad r=1,2$,

where $v^{r}$ is the destination-specific and unobserved individual effect. We assume that the unobserved heterogeneity is independent of observed characteristics and follows a Gamma distribution with unit mean and variance theta. In the proportional hazard $\mathrm{CRM}$, the interpretation of the parameters is analogous to the Cox PH model. The marginal effect of a certain variable ${ }^{x_{k}}$, on the chance of entering state $r$, is

$\partial h^{r}(t \mid x, \beta) / \partial x_{k}=h_{0}^{r}(t) \exp \left[x(t)^{\prime} \beta^{r}\right] \beta_{k}^{r}=\beta_{k}^{r} h^{r}(t \mid x, \beta)$.

When $\beta_{k}^{r}>0$, an increase in $x_{k}$ will increase the probability of leaving the pegged exchange rate system for a certain destination state $r$ relative to the probability of staying with the peg. The proportional hazard competing risks model also allows us to compare the odds of each type of exits. If $\beta_{k}^{r}>\beta_{k}^{j} \forall j \neq r$ then an increase in $x_{k}$ will increase the conditional probability of exiting from route $r$.

\section{Results}

To examine the general distribution of exits, we begin with a preliminary model without explanatory variables and the standard nonparametric Kaplan-Meier

\footnotetext{
${ }^{4}$ When unobserved heterogeneity is ignored, its impact is confounded with that of the baseline hazard, which might result in spurious regression.
} 
estimators. Figures 1-3 present the estimated hazard functions for both types of exits from a pegged exchange rate system. The results for all exits show a mildly nonmonotonic pattern of duration dependence. However, crisis-driven exits exhibit positive duration dependence in general, while orderly exits exhibit negative duration dependence. The estimated survival functions in Figure 4 show that orderly exits are more likely to occur in the early stage of a peg than those of crisis-driven exits.

\section{Figures 1 to 4 about here}

The estimation results for the standard Cox CRM are reported in Table 4. The results for Cox CRM with unobserved heterogeneity are reported in Table 5.

\section{Table 4 about here}

\section{Table 5 about here}

For both models, we control the country-specific time-varying explanatory variables. In the baseline Model (1), the selected variables include openness, trade concentration, inflation, output growth, output volatility, interest rate and capital-account liberalisation. Country-specific attributes are considered in models (2) to (5).

Note, from Table 5, that $\sigma_{v}^{2}$ is close to zero in all models, and we cannot reject the null hypothesis for $\sigma_{v}^{2}=0$. It is found that the main estimates are almost identical to those of the standard model. Furthermore, all the ${ }^{\sigma_{v}^{2}}$ except for the orderly exit in model 3 are close to zero. Therefore, the heterogeneity problem is not severe. The coefficient for the degrees of openness is negative in all cases. It is a significant consideration for orderly exits, but insignificant for crisis-driven exits. An increase in openness greatly reduces the chance of an orderly exit, implying that the benefit of trade openness outweighs the cost of vulnerability to external shocks. 
For the orderly exit, the coefficient for trade concentration is strongly negative in model (2). A high concentration of trade improves the linkage between the home and base countries, which in turn reduces the probability of an orderly exit. On the other hand, it will exacerbate a given misalignment and lead to a crisis-driven exit. Therefore, the crisis-driven exit coefficient is strongly positive in most models. The coefficient for the inflation rate is significantly positive for orderly exits but slightly negative for crisis-driven exits. A higher level of inflation in home country compared with that of the base country under the peg leads to overvaluation of the real exchange rate. Thus, abandoning the peg can result in a higher chance of an orderly exit and prove beneficial for a country's sustainable development. The coefficient for the degrees of capital-account liberalisation is significantly positive for orderly exits but insignificant for the crisis-driven exits. ${ }^{5}$ For countries with liberalised capital accounts, the floating exchange rate arrangement provides a better insulation for output against shocks to aggregate demand. It also implies that an orderly exit cannot occur when capital control is still in place.

Note that the effect of economic growth (GDP_GROWTH) is negative but insignificant in all models. The coefficients for the volatility of output (GDP_VOLATILITY) and the interest rate of the base country are strongly positive for both exits in most models. High volatility in output might lead a country to adopt a flexible exchange rate system to avoid economic shocks, thereby reducing the probability of the peg's survival. Increased interest rates of the base country accelerate capital outflows from the home country, forcing the abandonment of the peg. It is noteworthy that the estimated coefficient is larger for crisis-driven exits, suggesting that an increased interest rate in the base country will heighten the chance of a crisis-driven exit. Consequently, the peg requires the home country to follow the monetary policy of the base country. Such a policy might not be optimal ${ }^{6}$ and could potentially make the home economy more vulnerable to speculative attacks. ${ }^{7}$

\footnotetext{
${ }^{5}$ Glick et al. (2006) suggest that countries with liberalised capital accounts might also have better economic fundamentals, which make them less vulnerable to currency_crises.

${ }^{6}$ Miniane and Rogers (2007) find that local interest rates are more likely to follow base interest rates for pegs.

${ }^{7}$ Di Giovanni and Shambaugh (2007) find evidence that a high base-country interest rate has a contractionary effect on domestic economy, especially for the country with a fixed exchange rate.
} 
Our findings are robust across models, except for model (2), where controlling the degree of central bank independence (CBI) generates a negative coefficient for the volatility of output in the orderly-exit case. Some important results are obtained. First, a high turnover of central bank governors (less central bank independence) induces a higher likelihood of an orderly exit. Second, we find that the conditional probability of an exit is not affected by the degree of democracy, hyperinflation or whether the country is developed or developing. Note that hyperinflation reduces the probability of leaving the pegged exchange system. The peg provides a potential nominal anchor for a central bank to achieve its inflation target. Third, rapid growth in foreign currency reserves can defend the peg and reduce the probability of crisis-driven exits (Chong et al., 2008). Also, note that the coefficient for the net debt position variable is strongly negative for orderly exits. Calvo and Reinhart (2002) point out that foreign debt is the main contributing factor for a country to peg its currency in order to avoid exchange rate volatility. Thus, a high level of foreign liabilities reduces the tendency towards adopting a floating regime. Finally, the incidence of banking crises significantly increases the chance of crisis-driven exits, whereas it has no apparent effect on orderly exits.

After controlling the country-specific time-varying factors and unobserved heterogeneity (in model (1)), we retrieve the baseline hazard functions for both types of exits by Cox CRM. The smoothed versions of these functions are shown in Figures 5 and 6. Note that the hazard functions remain relatively unaffected; in addition, crisis-driven exits exhibit positive duration dependence, while orderly exits are more likely to occur at an early stage of the peg.

\section{Figures 5 to 6 about here}

\section{Conclusion}

For many developing countries, the fixed exchange rate regime serves as a temporary policy measure to stabilise domestic inflation and provide an environment for steady economic growth. However, pegs might also constrain the choice of domestic monetary policies and make the domestic financial system vulnerable to speculative 
attacks. This paper employs the competing risks model to investigate how a country's attributes affect its choice of the exchange rate regime. Two types of exits from the pegged exchange rate regime, namely, the crisis-driven exit and the orderly exit, are investigated. The two types of exits are very different in nature and in policy implications. A crisis-driven exit often results in economic turbulence, while an orderly exit is relatively tranquil. A competing risks model with time-varying explanatory variables is estimated to uncover the way that the peg duration affects the likelihoods of crisis-driven and orderly exits. The baseline hazard ratio estimated by Cox CRM reveals that crisis-driven exits exhibit positive duration dependence, while orderly exits exhibit negative duration dependence after controlling country-specific time-varying factors and unobserved heterogeneity. Second, it is found that countries with higher degrees of openness and trade concentration have a lower chance of orderly exits. Third, it is shown that capital-account liberalisation increases the chance of orderly exits, while it has no apparent effect on the likelihood of crisis-driven exits. Last but not least, it is found that the likelihood of crisis-driven exits increases with the incidences of banking crises.

\section{References:}

Calvo, G. and C. Reinhart (2002) "Fear of floating," Quarterly Journal of Economics 117(2), pp. 379-408.

Chong, T. T. L. (2000) "Estimating the differencing parameter via the partial autocorrelation function," Journal of Econometrics 97, pp. 365-381.

Chong, T. T. L., Q. He and M. Hinich (2008) "The nonlinear dynamics of foreign reserves and currency crises," Studies in Nonlinear Dynamics and Econometrics 12(4), Article 2.

D'Addio, A. C. and M. Rosholm (2005) "Exits from temporary jobs in Europe: a competing risks analysis," Labour Economics 12(4) pp. 449-468. 
Detragiache E., A. Mody and E. Okada (2005) "Exits from Heavily Managed Exchange Rate Regimes," IMF Working Paper, No. 39.

Di Giovanni, J. and J. Shambaugh (2007) "The impact of foreign interest rates on the economy: the role of the exchange rate regime," Journal of International Economics 74(2), pp. 341-361.

Duttagupta, R. and I. Otker-Robe (2003) "Exits from pegged regimes: an empirical analysis," IMF Working Paper, No.03/147.

Eichengreen, B. (1999) "Kicking the habit: moving from pegged rates to greater exchange rate flexibility," Economic Journal 109, pp. c1-c14.

Eichengreen, B., A. Rose, and C. Wyplosz (1994) "Speculative attacks on pegged exchange rates: an empirical exploration with special reference to the European monetary system," NBER working paper, No. 4898.

Flood, R. and P. Garber (1984) "Collapsing exchange-rate regimes: some linear examples," Journal of International Economics 17, pp. 1-13.

Ghosh, A., A. Gulde and H. Wolf (2003) Exchange Rate Regimes: Choices and Consequences, Cambridge, Mass., MIT Press.

Glick, R., X. Guo and M. Hutchison (2006) "Currency crises, capital-account liberalization, and selection bias," Review of Economics and Statistics 88(4), pp. 698714.

He, Q., T. T. L. Chong, L. Li and J. Zhang (2010) “A competing risks analysis of corporate survival," Financial Management 39(4), pp. 1697-1718.

Klein, M. and J. Shambaugh (2006) "The nature of exchange rate regimes," NBER Working Papers, No. 12729. 
Klein, M. and N. Marion (1997) "Explaining the duration of exchange-rate pegs," Journal of Development Economics 54(2), pp. 387-404.

Krugman, P. (1979) “A model of balance-of-payments crises," Journal of Money, Credit and Banking 11(3), pp. 311-325.

Lane, P. and G. Milesi-Ferretti (2007) "The external wealth of nations mark II: revised and extended estimates of foreign assets and liabilities, 1970-2004," Journal of International Economics 73(2), pp. 223-250.

Lin, S. and H. Ye (2011) "The role of financial development in exchange rate regime choices," Journal of International Money and Finance 30, pp. 641-659.

Manton, K., E. Stallard and J. Vaupel (1986) "Alternative models for the heterogeneity of mortality risks among the aged," Journal of the American Statistical Association 81(395), pp. 635-644.

Masson P. and F. J. Ruge-Murcia (2005) "Explaining the transition between exchange rate regimes," Scandinavian Journal of Economics 107(2), pp. 261-278.

Miniane, J. and J. Rogers (2007) "Capital controls and the international transmission of U.S. money shocks," Journal of Money, Credit and Banking 39(5), pp. 1003-1035.

Rebelo, S. and C. Vegh (2008) "When is it optimal to abandon a fixed exchange Rate?" Review of Economic Studies 73(3), pp. 929-955.

Rinehart, C. and K. Rogoff (2004) "The modern history of exchange rate arrangements: a reinterpretation," Quarterly Journal of Economics 119(1), pp. 1-48.

Shambaugh, J. (2004) "The effect of fixed exchange rates on monetary policy," Quarterly Journal of Economics 119(1), pp. 301-352.

Tamgac, U. (2013) "Duration of fixed exchange rate regimes in emerging economies," Journal of International Money and Finance 37, pp. 439-467 
Walti, S. (2005) "The duration of fixed exchange rate regimes," IIIS Discussion Paper, No. 96.

Figure 1: Estimated hazard function for all types of exits

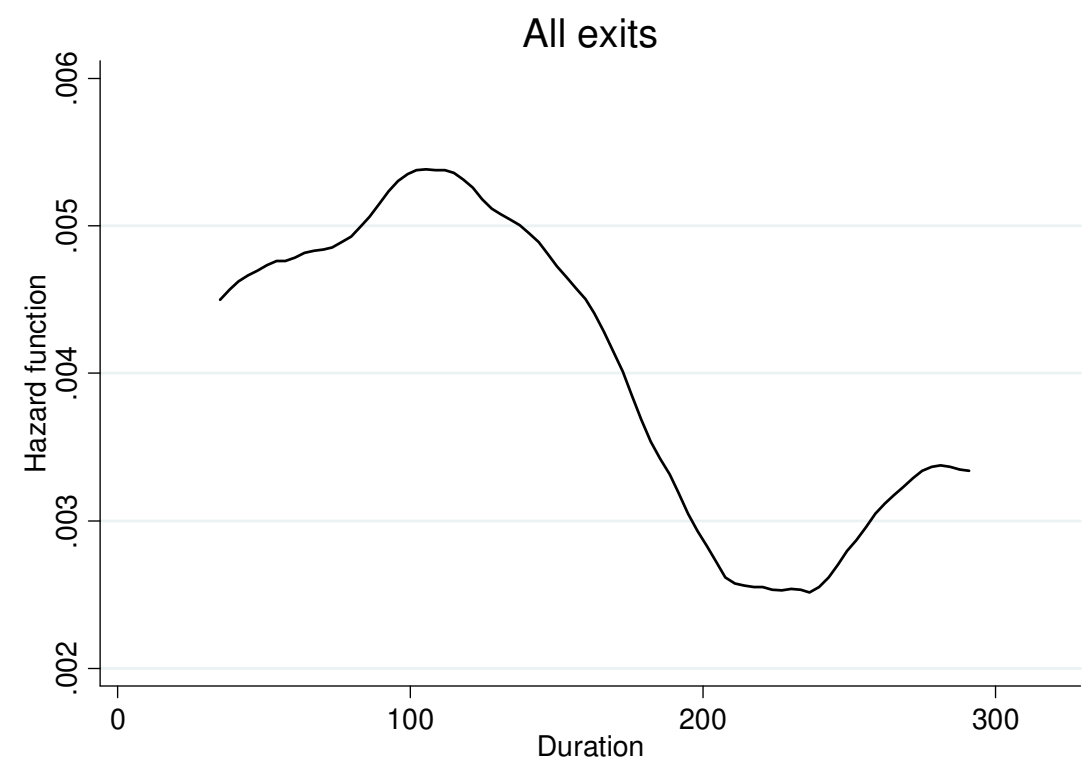

Figure 2: Estimated hazard function for crisis-driven exits

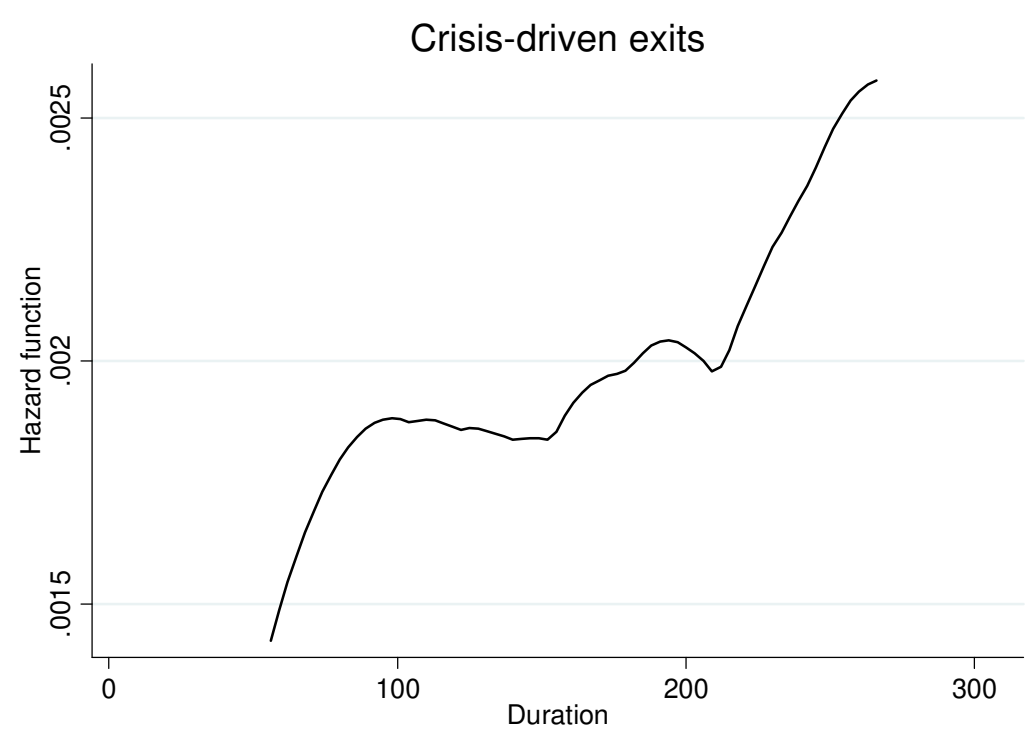


Figure 3: Estimated hazard function for orderly exits

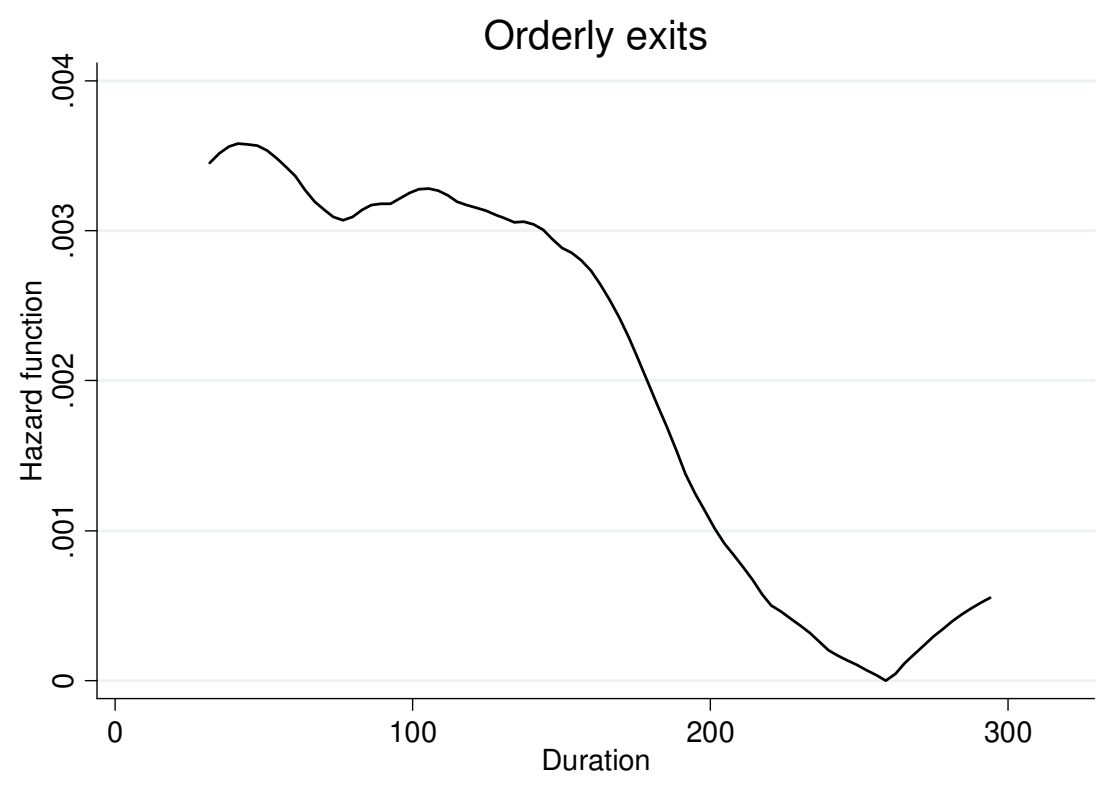

Figure 4: Estimated survival functions 


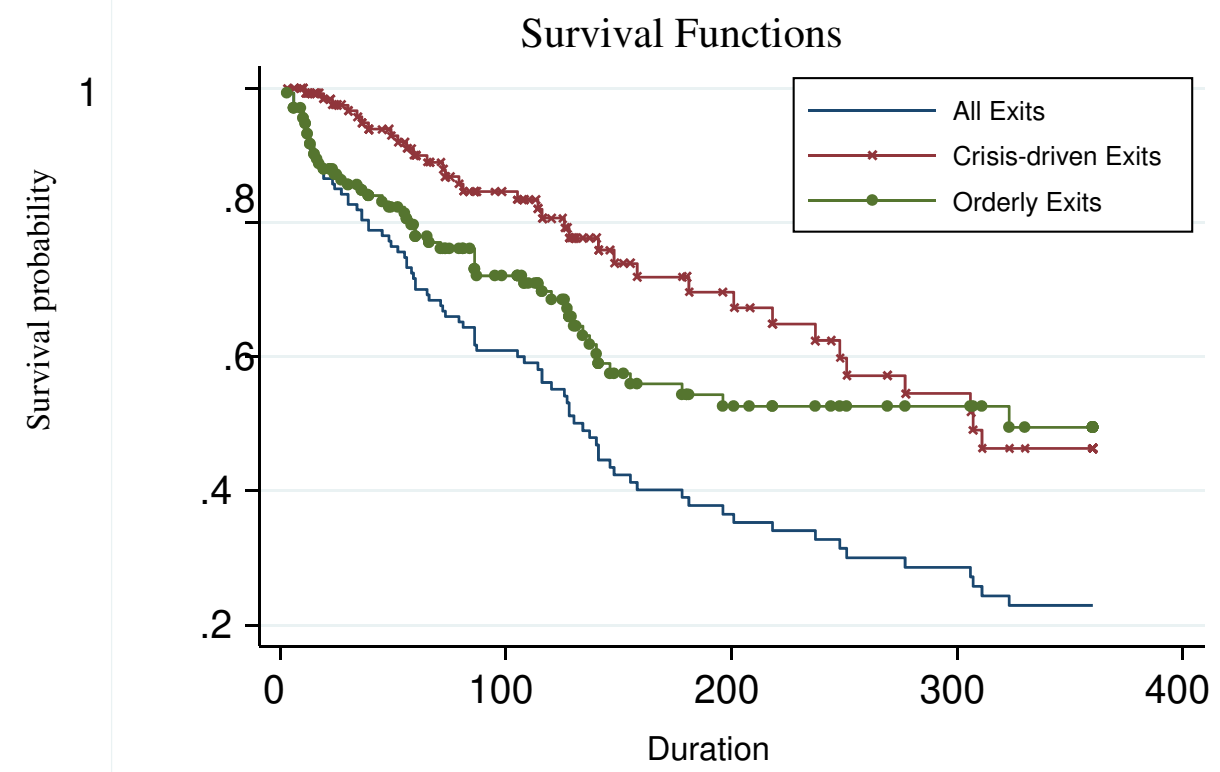

Figure 5 Estimated Cox hazard function for Crisis-driven exits

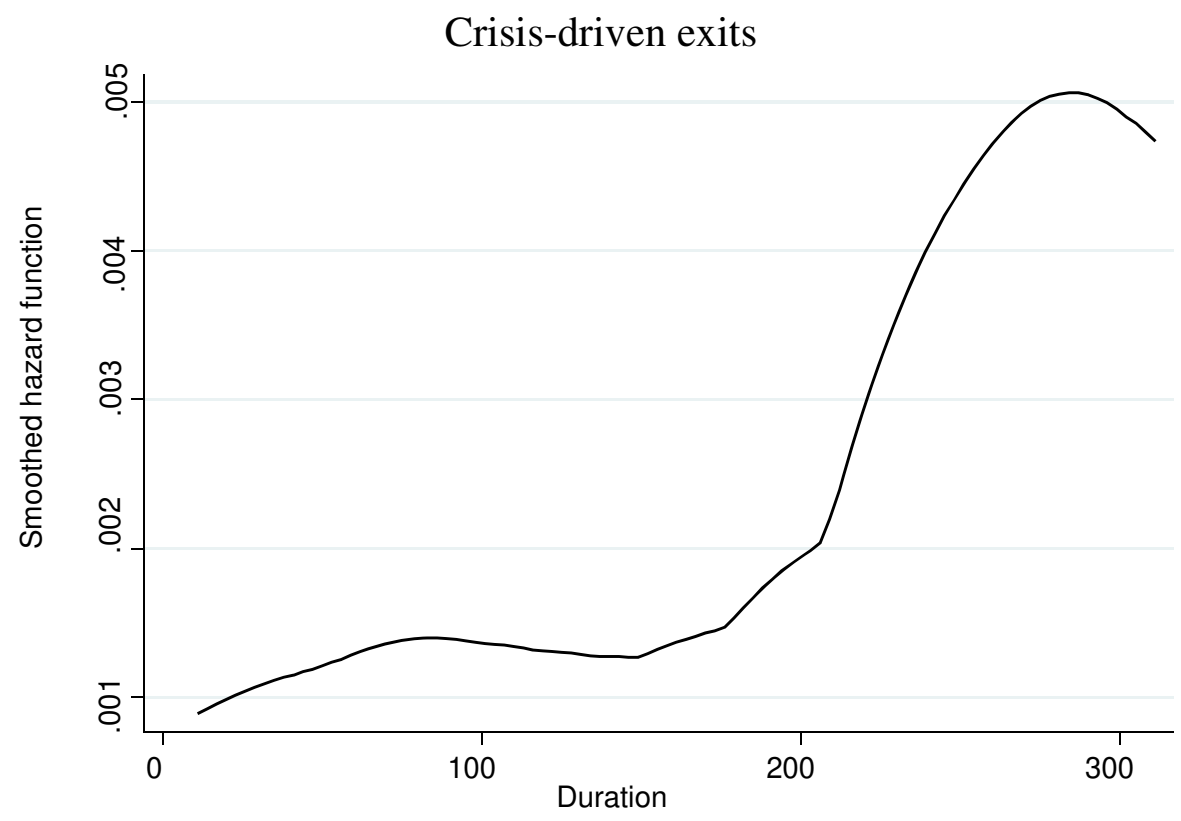

Figure 6 Estimated Cox hazard function for Orderly exits 


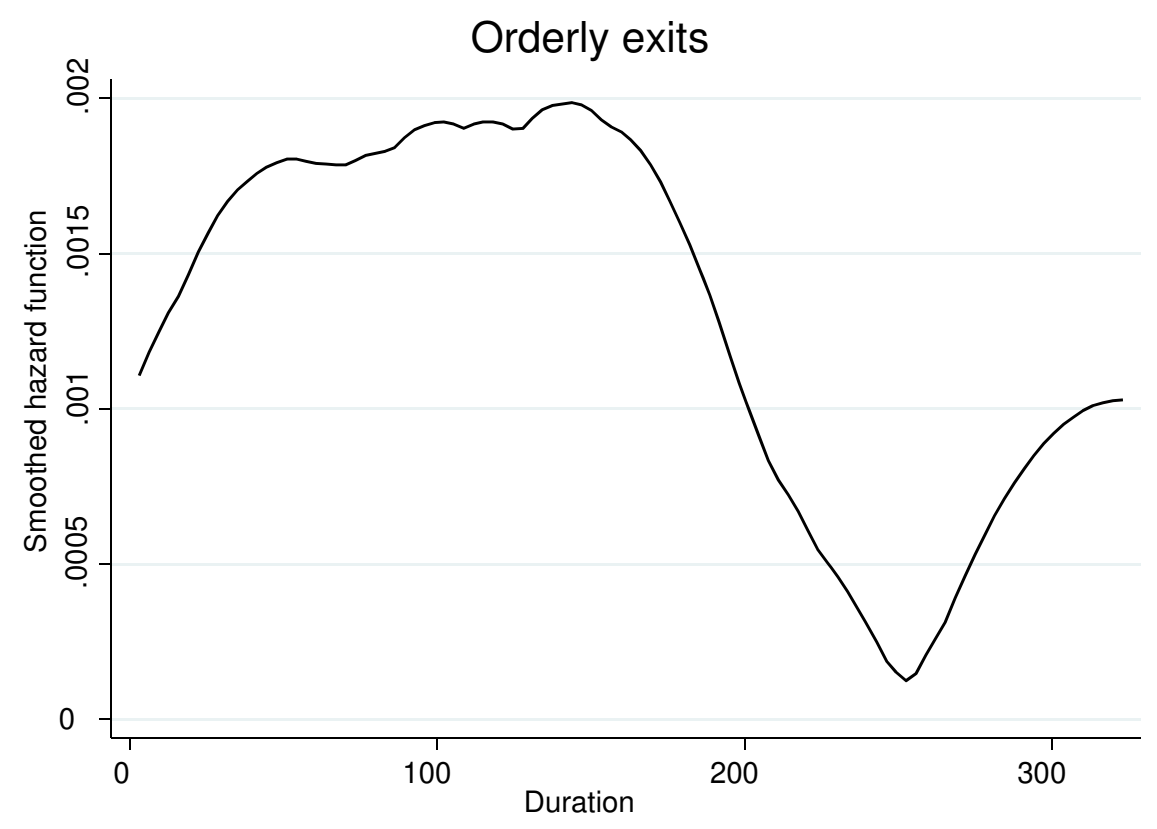

Table 2: Nature of Exits

\begin{tabular}{llll}
\hline Country & Period of Exits & $\begin{array}{l}\text { Duration of } \\
\text { Pegged Regime }\end{array}$ & Nature of Exits \\
\hline Argentina & $1981: 03$ & 36 & Orderly exit \\
& $1986: 04$ & 10 & Orderly exit \\
& $2001: 12$ & 128 & Crisis-driven exit \\
Armenia & & 73 & Non-exit \\
Australia & $1982: 11$ & 130 & Orderly exit \\
Austria & & 360 & Non-exit \\
Belgium & & 360 & Non-exit \\
Bolivia & & 180 & Non-exit \\
Brazil & $1975: 04$ & 39 & Orderly exit \\
& $1986: 09$ & 6 & Orderly exit \\
& $1989: 04$ & 3 & Orderly exit \\
Bulgaria & $1999: 02$ & 55 & Orderly exit \\
Canada & & 60 & Non-exit \\
Chile & $1982: 06$ & 360 & Non-exit \\
& $1999: 09$ & 52 & Crisis-driven exit \\
China & $1981: 03$ & 86 & Orderly exit \\
& & 140 & Orderly exit \\
Colombia & $1983: 10$ & 141 & Non-exit \\
Costa Rica & $1999: 10$ & 178 & Orderly exit \\
Cyprus & $1980: 10$ & 105 & Orderly exit \\
Czech Rep & $1997: 06$ & 218 & Crisis-driven exit \\
Denmark & & 360 & Non-exit \\
& & 360 & Non-exit \\
& & & Crisis-driven exit \\
& & & Non-exit \\
& & &
\end{tabular}




\begin{tabular}{|c|c|c|c|}
\hline Dominica & & 360 & Non-exit \\
\hline Dominican Rep & 1982:09 & 128 & Orderly exit \\
\hline & 1987:07 & 19 & Crisis-driven exit \\
\hline & & 110 & Non-exit \\
\hline Ecuador & 1982:03 & 108 & Orderly exit \\
\hline & $1997: 10$ & 48 & Orderly exit \\
\hline & & 22 & Non-exit \\
\hline Egypt & & 360 & Non-exit \\
\hline El Salvador & 1982:08 & 127 & Orderly exit \\
\hline & & 141 & Non-exit \\
\hline Estonia & & 114 & Non-exit \\
\hline Finland & 1992:09 & 248 & Crisis-driven exit \\
\hline & & 107 & Non-exit \\
\hline France & 1974:04 & 27 & Orderly exit \\
\hline & & 330 & Non-exit \\
\hline Germany & 1973:01 & 12 & Orderly exit \\
\hline & & 36 & Non-exit \\
\hline Greece & 1981:07 & 114 & Crisis-driven exit \\
\hline & & 208 & Non-exit \\
\hline Guatemala & 1984:12 & 155 & Orderly-exit \\
\hline & 1989:06 & 11 & Crisis-driven exit \\
\hline & & 128 & Non-exit \\
\hline Guyana & 1987:02 & 181 & Crisis-driven exit \\
\hline & & 84 & Non-exit \\
\hline Haiti & 1991:10 & 237 & Crisis-driven exit \\
\hline & 1993:05 & 13 & Orderly-exit \\
\hline Honduras & 1990:03 & 218 & Crisis-driven exit \\
\hline & & 129 & Non-exit \\
\hline Hong Kong & & 360 & Non-exit \\
\hline Hungary & & 360 & Non-exit \\
\hline Iceland & 1973:05 & 16 & Orderly-exit \\
\hline & 1977:05 & 15 & Orderly-exit \\
\hline & $2000: 10$ & 196 & Orderly-exit \\
\hline India & 1979:03 & 86 & Orderly-exit \\
\hline & & 269 & Non-exit \\
\hline Indonesia & 1972:07 & 6 & Orderly-exit \\
\hline & 1997:08 & 277 & Crisis-driven exit \\
\hline Iran & 1977:01 & 60 & Orderly-exit \\
\hline Iraq & 1982:01 & 120 & Orderly-exit \\
\hline Ireland & & 360 & Non-exit \\
\hline Israel & 1986:09 & 11 & Orderly-exit \\
\hline & & 180 & Non-exit \\
\hline Italy & $1975: 10$ & 45 & Orderly-exit \\
\hline & 1992:09 & 116 & Crisis-driven exit \\
\hline & & 105 & Non-exit \\
\hline Jamaica & 1978:01 & 72 & Crisis-driven exit \\
\hline & 1990:10 & 137 & Orderly-exit \\
\hline & & 108 & Non-exit \\
\hline
\end{tabular}




\begin{tabular}{|c|c|c|c|}
\hline Japan & $1977: 12$ & 71 & Orderly-exit \\
\hline \multirow[t]{2}{*}{ Jordan } & 1988:10 & 201 & Crisis-driven exit \\
\hline & & 152 & Non-exit \\
\hline Korea & $1997: 12$ & 311 & Crisis-driven exit \\
\hline \multirow[t]{2}{*}{ Lao } & 1973:04 & 15 & Orderly-exit \\
\hline & 1997:01 & 79 & Crisis-driven exit \\
\hline Latvia & & 95 & Non-exit \\
\hline \multirow[t]{2}{*}{ Lebanon } & 1984:03 & 146 & Orderly-exit \\
\hline & & 125 & Non-exit \\
\hline Lithuania & & 81 & Non-exit \\
\hline \multirow[t]{2}{*}{ Malaysia } & 1997:08 & 307 & Crisis-driven exit \\
\hline & & 39 & Non-exit \\
\hline \multirow[t]{3}{*}{ Mexico } & 1976:09 & 56 & Crisis-driven exit \\
\hline & 1982:02 & 59 & Crisis-driven exit \\
\hline & 1995:01 & 73 & Crisis-driven exit \\
\hline \multirow[t]{2}{*}{ Moldova } & 1998:06 & 39 & Crisis-driven exit \\
\hline & & 22 & Non-exit \\
\hline \multirow[t]{5}{*}{ Myanmar } & 1974:07 & 30 & Orderly-exit \\
\hline & 1983:05 & 86 & Orderly-exit \\
\hline & 1988:04 & 24 & Orderly-exit \\
\hline & 1993:01 & 19 & Orderly-exit \\
\hline & 1996:08 & 30 & Orderly-exit \\
\hline Netherlands & & 360 & Non-exit \\
\hline New Zealand & 1985:03 & 158 & Crisis-driven exit \\
\hline \multirow[t]{2}{*}{ Nicaragua } & 1974:04 & 87 & Non-exit \\
\hline & & 128 & Orderly-exit \\
\hline \multirow[t]{2}{*}{ Norway } & 1982:07 & 126 & Crisis-driven exit \\
\hline & 1992:12 & 65 & Crisis-driven exit \\
\hline Pakistan & & 360 & Non-exit \\
\hline Panama & & 360 & Non-exit \\
\hline \multirow[t]{3}{*}{ Paraguay } & 1981:09 & 116 & Orderly-exit \\
\hline & 1989:03 & 34 & Crisis-driven exit \\
\hline & & 131 & Non-exit \\
\hline Peru & & 98 & Non-exit \\
\hline \multirow[t]{2}{*}{ Philippines } & 1983:10 & 141 & Crisis-driven exit \\
\hline & 1997:07 & 128 & Crisis-driven exit \\
\hline \multirow[t]{2}{*}{ Poland } & 1991:06 & 17 & Orderly-exit \\
\hline & 2000:04 & 58 & Orderly-exit \\
\hline Portugal & & 360 & Non-exit \\
\hline Romania & & 9 & Non-exit \\
\hline Russia & & 25 & Non-exit \\
\hline Singapore & 1998:12 & 323 & Orderly-exit \\
\hline Slovak Rep & 1998:10 & 66 & Orderly-exit \\
\hline Slovenia & & 105 & Non-exit \\
\hline South Africa & $1972: 11$ & 10 & Orderly-exit \\
\hline Spain & & 360 & Non-exit \\
\hline Sweden & 1992:12 & 251 & Crisis-driven exit \\
\hline Switzerland & 1973:12 & 13 & Orderly-exit \\
\hline
\end{tabular}




\begin{tabular}{llll} 
Thailand & $1997: 07$ & 244 & Non-exit \\
Turkey & $1976: 09$ & 306 & Crisis-driven exit \\
& $2001: 02$ & 56 & Orderly-exit \\
UK & $1972: 07$ & 6 & Crisis-driven exit \\
& $1992: 09$ & 23 & Orderly-exit \\
US & $1978: 02$ & 60 & Crisis-driven exit \\
Ukraine & & 39 & Orderly-exit \\
Uruguay & $1982: 12$ & 49 & Non-exit \\
& $1991: 12$ & 12 & Crisis-driven exit \\
Venezuela & $1983: 03$ & 75 & Orderly-exit \\
& & 134 & Non-exit \\
& & 66 & Orderly-exit \\
\hline
\end{tabular}


Table 4: Estimation Results for Cox Model

\begin{tabular}{|c|c|c|c|c|c|c|c|c|c|c|}
\hline \multirow[b]{3}{*}{ Risk Coefficient } & \multicolumn{2}{|c|}{ Model 1} & \multicolumn{2}{|c|}{ Model 2} & \multicolumn{2}{|c|}{ Model 3} & \multicolumn{2}{|c|}{ Model 4} & \multicolumn{2}{|c|}{ Model 5} \\
\hline & Risk 1 & Risk 2 & Risk 1 & Risk 2 & Risk 1 & Risk 2 & Risk 1 & Risk 2 & Risk 1 & Risk 2 \\
\hline & 40 & 29 & 34 & 26 & 36 & 28 & 36 & 29 & 37 & 29 \\
\hline OPENNESS & $-2.767 * * *$ & -0.411 & $-1.372 *$ & -0.321 & $-1.792 * *$ & -0.251 & $-3.203 * * *$ & -0.25 & $-3.343 * * *$ & -0.459 \\
\hline CONCENTRATION & -0.014 & $0.021 *$ & $-0.019 *$ & 0.018 & -0.012 & $0.021 *$ & -0.012 & $0.020 *$ & -0.009 & $0.024 *$ \\
\hline INFLATION & $0.431 * * *$ & -1.131 & $0.481 * * *$ & -4.821 & $0.454 * * *$ & -3.093 & $0.565^{* * *}$ & -1.182 & $0.475^{* * * *}$ & -1.922 \\
\hline GDP_GROWTH & -1.397 & -1.323 & -0.155 & -1.792 & -1.056 & -1.162 & 0.711 & -0.993 & -0.109 & -1.343 \\
\hline GDP_VOLATILITY & $11.293 *$ & $12.725^{* *}$ & -0.208 & $13.558 * *$ & 9.58 & $13.448 * *$ & $15.601 * *$ & $12.950 * *$ & $15.678 * *$ & $9.724 *$ \\
\hline BASEINTEREST & $15.643 * * *$ & $22.927 * * *$ & $14.254 * *$ & $33.794 * * *$ & $18.273 * * *$ & $32.244 * * *$ & $13.375 * *$ & $21.416 * * *$ & $14.399 * *$ & $21.141 * * *$ \\
\hline CAL & $1.381 * * *$ & -0.619 & $1.201 * *$ & -0.597 & $1.460 * *$ & -0.681 & $1.288 * *$ & -0.653 & $1.383 * *$ & -0.646 \\
\hline CBI & & & $1.624 * * *$ & 0.755 & & & & & & \\
\hline COUNTRYTYPE & & & 0.235 & -0.146 & & & & & & \\
\hline DEMOCRACY & & & & & -0.133 & -0.019 & & & & \\
\hline DEBTPOSITION & & & & & $-0.811^{*}$ & -0.117 & & & & \\
\hline RESERVEGROWTH & & & & & & & $-0.850 *$ & $-1.009 * *$ & & \\
\hline HYPERINFLATION & & & & & & & -1.267 & -0.392 & -1.279 & -0.629 \\
\hline BANKCRISIS & & & & & & & & & -0.056 & $0.989 * *$ \\
\hline $\ln \mathrm{L}$ & -240.82 & & -194.32 & & -213.71 & & -215.38 & & -217.97 & \\
\hline
\end{tabular}

* significant at 10\%; ** significant at 5\%; *** significant at 1\%, Risk 1 for orderly exits, Risk 2 for crisis-driven exits. 
Table 5: Estimation Results for Cox Model With Gamma Heterogeneity

\begin{tabular}{|c|c|c|c|c|c|c|c|c|c|c|}
\hline \multirow[b]{3}{*}{ Risk Coefficient } & \multicolumn{2}{|c|}{ Model 1} & \multicolumn{2}{|c|}{ Model 2} & \multicolumn{2}{|c|}{ Model 3} & \multicolumn{2}{|c|}{ Model 4} & \multicolumn{2}{|c|}{ Model 5} \\
\hline & Risk 1 & Risk 2 & Risk 1 & Risk 2 & Risk 1 & Risk 2 & Risk 1 & Risk 2 & Risk 1 & Risk 2 \\
\hline & 40 & 29 & 34 & 26 & 36 & 28 & 36 & 29 & 37 & 29 \\
\hline OPENNESS & $-2.780 * * *$ & -0.411 & $-1.381 *$ & -0.321 & $-1.586 * *$ & -0.251 & $-3.120 * * *$ & -0.25 & $-3.265 * * *$ & -0.459 \\
\hline CONCENTRATION & -0.014 & $0.021 *$ & $-0.019 *$ & 0.018 & -0.018 & $0.021 *$ & -0.016 & $0.020 *$ & -0.013 & $0.024 *$ \\
\hline INFLATION & $0.430 * * *$ & -1.131 & $0.478 * * *$ & -4.821 & $0.421 * * *$ & -3.093 & $0.553 * * *$ & -1.182 & $0.460 * * *$ & -1.922 \\
\hline GDP_GROWTH & -1.359 & -1.323 & -0.119 & -1.792 & -1.533 & -1.162 & 0.597 & -0.993 & -0.347 & -1.343 \\
\hline GDP_VOLATILITY & $11.374^{*}$ & $12.725 * *$ & -0.019 & $13.558 * *$ & 9.251 & $13.448 * *$ & $15.260 * *$ & $12.950 * *$ & $15.293 * *$ & $9.724 *$ \\
\hline BASEINTEREST & $15.860 * * *$ & $22.93 * * *$ & $14.270 * *$ & $33.794 * * *$ & $18.856 * * *$ & $32.244 * * *$ & $13.477 * *$ & $21.416 * * *$ & $14.595 * *$ & $21.141 * * *$ \\
\hline CAL & $1.369 * * *$ & -0.619 & $1.200 * *$ & -0.597 & $1.376 * *$ & -0.681 & $1.283 * *$ & -0.653 & $1.393 * *$ & -0.646 \\
\hline CBI & & & $1.635 * * *$ & 0.755 & & & & & & \\
\hline COUNTRYTYPE & & & 0.236 & -0.146 & & & & & & \\
\hline DEMOCRACY & & & & & -0.189 & -0.019 & & & & \\
\hline DEBTPOSITION & & & & & $-0.803^{*}$ & -0.117 & & & & \\
\hline RESERVEGROWTH & & & & & & & $-0.863^{*}$ & $-1.009 * *$ & & \\
\hline HYPERINFLATION & & & & & & & -1.396 & -0.392 & -1.426 & -0.629 \\
\hline BANKCRISIS & & & & & & & & & -0.062 & $0.989 * *$ \\
\hline$\sigma_{v}^{2}$ & $1.36 \mathrm{e}-15$ & $2.11 \mathrm{e}-16$ & $1.27 \mathrm{e}-14$ & $7.00 \mathrm{e}-19$ & 0.152 & $2.11 \mathrm{e}-16$ & 0.061 & $2.08 \mathrm{e}-18$ & 0.071 & $1.27 \mathrm{e}-14$ \\
\hline $\ln \mathrm{L}$ & -240.57 & & -194.20 & & -213.21 & & -214.97 & & -217.58 & \\
\hline
\end{tabular}

* significant at 10\%; ** significant at 5\%; *** significant at 1\%, Risk 1 for orderly exits, Risk 2 for crisis-driven exits. 